\title{
Signalling by insulin and IGF receptors: supporting acts and new players
}

\author{
Kenneth Siddle \\ Department of Clinical Biochemistry, Institute of Metabolic Science, Addenbrooke's Hospital, University of Cambridge Metabolic Research Laboratories, Cambridge CB2 0QQ, UK
}

(Correspondence should be addressed to K Siddle; Email: ks14@mole.bio.cam.ac.uk)

\begin{abstract}
The signalling pathways utilised by insulin receptor (IR) and IGF receptor to transduce their diverse effects on cellular metabolism, growth and survival are well established in broad outline, but many details remain to be elucidated. Tyrosine phosphorylation of IR substrates and Shc initiates signalling via canonical phosphoinositide 3-kinase/Akt and Ras/MAP kinase pathways, which together mediate many of the actions of insulin and IGFs. However, a variety of additional substrates and scaffolds have been described that may play roles in modulating the canonical pathways or in specific biological responses. This review will focus on recent studies that have extended our understanding of insulin/IGF signalling pathways, and the elements that may contribute to specificity.
\end{abstract}

Journal of Molecular Endocrinology (2011) 47, R1-R10

\section{Introduction}

Insulin and the insulin-like growth factors (IGFs) control many aspects of metabolism, growth and survival in a wide range of mammalian tissues (Nakae et al. 2001). Insulin/IGF signalling also contributes to regulation of lifespan (Narasimhan et al. 2009), while dysregulation of signalling has been implicated in neoplasia (Pollak 2008). Although insulin and IGFs play distinct physiological roles, they utilise the same signalling pathways, involving phosphoinositide 3-kinase (PI3K) and Akt or Ras and MAP kinase, which mediate responses to many other cellular stimuli. In large part, stimulus/response specificity must reflect the levels of expression of receptors and downstream targets in different tissues together with combinatorial effects (Dumont et al. 2002). However, it is widely assumed that specificity is also imparted by differences in ligand binding and intrinsic signalling capacities of the insulin and IGF receptors (IGFRs). This review focuses on recent advances in understanding receptorproximal signalling mechanisms, including factors that may contribute to specificity of insulin and IGF action.

\section{Receptors}

The insulin receptor (IR) exists as two isoforms differing by the presence (IR-B) or absence (IR-A) of 12 amino acids at the carboxyl terminus of the $\alpha$-subunit, as a result of alternative splicing of the sequence encoded by exon 11 . In the type 1 IGFR, the corresponding sequence is always lacking. IR-B is the more abundant isoform in muscle, liver and fat. Insulin binds with similar affinity to both isoforms, but IGFs, and particularly IGF2, have greater affinity for IR-A than IR-B such that IR-A is a significant mediator of IGF2 action at physiological concentrations. Some studies have indicated that IR-B may signal more efficiently to metabolic endpoints and IR-A to mitogenic endpoints (Belfiore et al. 2009). It has been suggested that IR isoforms localise to different lipid raft microdomains within which distinct signalling complexes are assembled (Leibiger et al. 2010a).

Additional complexity arises from hetero-dimerisation of pro-receptors, generating insulin/IGF hybrid receptors. Both IR isoforms can form hybrids with IGFR as well as with each other. Hetero-dimerisation occurs with similar efficiency to homo-dimerisation, so that if one receptor is expressed in excess, the less abundant is assembled largely into hybrids. Hybrids bind IGFs with similar affinity to IGFR, but bind insulin with substantially lower affinity than IR (Belfiore $e$ t al. 2009). It is unclear whether hybrid receptors have a distinct physiological role.

\section{Receptor structure}

The structure of the IR ectodomain explains many features of ligand binding (Lawrence et al. 2007). 
Relative to the plasma membrane, the ectodomain has a folded-over conformation in which the two half-receptors lie anti-parallel and surround a ligandbinding pocket. The most significant structural differences between IR and IGFR are in the regions governing ligand specificity. Attempts to co-crystallise ligand-receptor complexes have been unsuccessful but other evidence indicates that high-affinity ligand binding involves contacts in trans with both halfreceptors (De Meyts 2008). Despite the dimeric receptor structure, only a single molecule of ligand can make all the contacts required to bind with high affinity and binding therefore demonstrates negative cooperativity, fitting a harmonic oscillator model (Kiselyov et al. 2009). The contacts made by individual ligands and kinetics of ligand-receptor interaction may influence the extent, duration and perhaps even the nature of receptor activation. Specificity has been reported in the responses elicited by different ligands acting on the same receptor (Jensen \& De Meyts 2009).

\section{Receptor trafficking}

As well as initiating intracellular signalling, ligandinduced autophosphorylation triggers internalisation of ligand/receptor complexes, leading to dissociation and degradation of ligand in the intracellular endosome/lysosome system and inactivation and recycling of receptors (Foti et al. 2004). However, receptor internalisation may also play an active role in signalling, particularly via the Ras/MAP kinase pathway to 'mitogenic' endpoints (Jensen \& De Meyts 2009). Internalisation and recycling of IGFR may sustain IGFinduced Akt phosphorylation (Romanelli et al. 2007). More controversially, it has been reported that IR signalling complexes are recruited to specific insulininducible gene loci (Nelson et al. 2011) and that nuclear IGFR binds to chromatin and acts directly as a transcriptional enhancer (Aleksic et al. 2010, Sehat et al. 2010). Sumoylation may play a role in nuclear targeting of IGFR (Sehat et al. 2010), but the pathways by which active receptors could traffic to the nucleus are unclear.

\section{Receptor regulation}

Internalised receptors are inactivated by phosphotyrosine-specific phosphatases, particularly PTP1B, which is localised to the cytosolic face of the endoplasmic reticulum (Dube \& Tremblay 2005). IR and IGFR function is regulated by a variety of mechanisms (Youngren 2007). The membrane glycoprotein PC-1, an ecto-nucleotide pyrophosphatase and phosphodiesterase, binds to the IR $\alpha$-subunit and inhibits insulin-induced TK activity (Goldfine et al. 2008).
SOCS proteins induced by cytokine signalling inhibit tyrosine phosphorylation of IRSs through competition at the docking site on the IR (Lebrun \& Van Obberghen 2008). The actions of Grb10 and Grb14 adaptors are potentially complex. It is not clear whether the expression and function of Grb10/14 are regulated or they act constitutively. Binding of Grb10/14 to autophosphorylated IR/IGFR (and some other RTKs) via their Src homology-2 (SH2) domains inhibits TK activity and IRS phosphorylation (Holt \& Siddle 2005). However, Grb10/14 also protect phosphotyrosines in the TK regulatory loop from dephosphorylation, effectively prolonging receptor activation (Nouaille et al. 2006, Smith et al. 2007). Grb10 additionally promotes receptor degradation by recruitment of the ubiquitin ligase NEDD4 (Vecchione et al. 2003, Ramos et al. 2006), while both Grb10 and Grb14 recruit additional protein-binding partners with potential signalling roles (Holt \& Siddle 2005). Gene deletion studies in mice confirm that Grb10 and Grb14 act as inhibitors of insulin signalling in vivo, with some specificity that probably reflects their different interactions and tissue distributions (Holt et al. 2009). Expression of the Grb10 gene is imprinted from each of the parental alleles in a tissue-specific manner, and ablation of individual alleles has distinct effects on foetal growth (through maternal allele, widely expressed) and adult behaviour (through paternal allele, expressed in brain) which may not be dependent on insulin/IGF signalling (Garfield et al. 2011).

\section{Canonical signalling pathways}

The major signalling pathways by which IR and IGFR regulate metabolism and gene expression, with central roles for the serine kinases Akt/PKB and MEK kinase, are well established (Adams et al. 2004, Cohen 2006, Taniguchi et al. 2006, Laviola et al. 2007). Activation of these kinases is dependent on the phosphorylation of IR substrates (principally IRS1 and -2) and Shc, leading to activation of PI3K and the small G-protein Ras (Fig. 1).

\section{PI3K/Akt pathway}

IRSs are relatively specific substrates of IR/IGFR, reflecting the role of IRS phosphotyrosine binding (PTB) and pleckstrin homology (PH) domains in recruitment by these receptors (White 2002). IRS2 additionally interacts directly with the tyrosine kinase domains (Wu et al. 2008). Tyrosine phosphorylation of IRSs creates binding sites for SH2 domains of various proteins, notably the regulatory subunits of class Ia PI3Ks and the adaptor Grb2 and also the phosphatase SHP2 and the Src family kinase Fyn. The sequence 


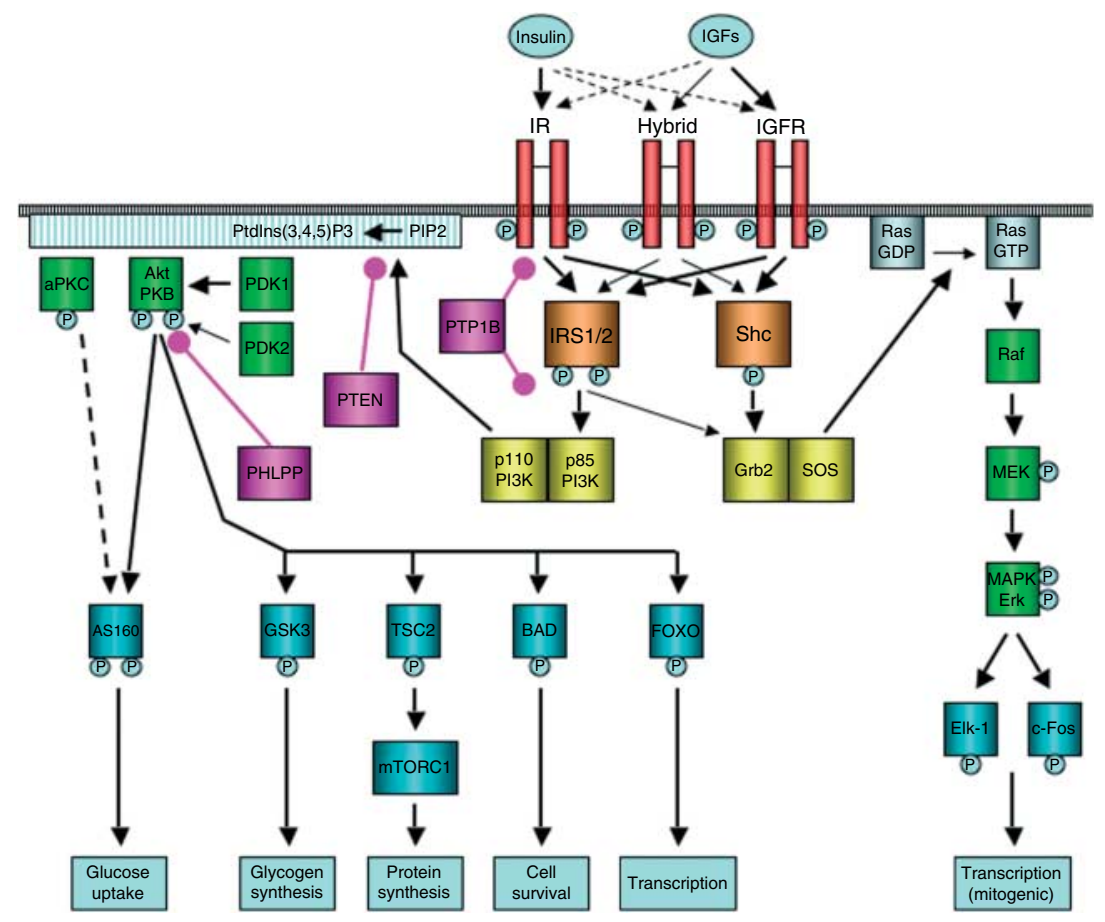

Figure 1 Canonical signalling pathways. The principal components of the PI3K/Akt and Ras/MAP kinase pathways are indicated: receptors (in red), tyrosine-phosphorylated substrates (in orange), adaptors and transducers (in yellow and grey), serine/threonine kinases (in green), serine/threonine phosphorylated substrates and downstream components (in blue) and negative regulators (in purple).

context of phosphotyrosines determines specificity of SH2 binding, the three residues immediately downstream being particularly important although such motifs do not fully explain selectivity (Liu et al. 2010). In terms of downstream signalling, IRS1 appears to be linked to glucose homeostasis and IRS2 to regulation of lipid metabolism (Taniguchi et al. 2005, Bouzakri et al. 2006, Thirone et al. 2006), though the mechanisms underlying this specificity are unclear. IRS1 and -2 recruit a similar spectrum of proteins including PI3Ks, although some differential interactions have been identified (Hanke \& Mann 2009). Functional specificity might also arise from differences in the kinetics of phosphorylation or the subcellular localisation of IRSs.

IRSs are regulated by feedback mechanisms and crosstalk from other pathways. IRS1 is phosphorylated on multiple serine/threonine residues by kinases downstream in the insulin signalling pathway, including Akt/PKB, S6K1 and glycogen synthase kinase-3 (GSK3), and in other pathways, including AMPK, PKCs, Jnk and IKK $\beta$ (Boura-Halfon \& Zick 2009, Sun \& Liu 2009). In general, serine/threonine phosphorylation inhibits IRS1 function (by promoting degradation, inhibiting interaction with IR/IGFR or inhibiting association of SH2 domains) although phosphorylation at certain sites can potentiate IRS1 tyrosine phosphorylation. Serine phosphorylation of IRS2 has been less studied, but is likely to be equally complex (Fritsche et al. 2011). Subversion of physiological regulatory mechanisms by lipid metabolites, adipokines or inflammatory mediators is believed to contribute to insulin resistance associated with pathological states, including obesity (Boura-Halfon \& Zick 2009, Sun \& Liu 2009). However, insulin signalling can also be modulated by other mechanisms and at other sites downstream of IRSs (Taniguchi et al. 2006, Hoehn et al. 2008, Li et al. 2010). Such controls may be tissue specific and, because of the branching nature of insulin/IGF signalling pathways, selective in terms of the biological responses affected. Genome-wide scanning revealed multiple negative regulators of insulin signalling, including previously uncharacterised proteins as well as diverse phosphatases and kinases (Huang et al. 2009).

Reversible modification of protein serine/threonine residues also occurs by $O$-GlcNAcylation, and is thought to affect a large number of cytoplasmic and nuclear proteins. The modification potentially provides a mechanism of crosstalk with phosphorylation, regulating protein stability and subcellular localisation and protein-protein interactions (Zeidan \& Hart 2010). Several components of insulin signalling pathways, 
including IRS1, are transiently modified by $O$-GlcNAc following insulin stimulation, and this in turn modulates their serine phosphorylation and attenuates insulin signal transduction (Yang et al. 2008). IRS1 is $O$-GlcNAcylated at multiple sites in close proximity to SH2 domain-binding motifs (Klein et al. 2009), and pharmacological elevation of $O$-GlcNAcylation inhibits tyrosine phosphorylation of PI3K-binding motifs (Whelan et al. 2010). O-GlcNAcylation is a nutrientand stress-sensitive modification, reflecting dependence on the hexosamine biosynthetic pathway, and it may contribute to diabetes-associated insulin resistance (Slawson et al. 2010).

Both IRS1 and -2 possess multiple tyrosines within YxxM motifs which, following phosphorylation, recruit the tandem SH2 domains of class Ia regulatory subunits (White 2002). Both regulatory and catalytic subunits of PI3Ks exist as multiple isoforms (p85 $\alpha / \mathrm{p} 55 \alpha / \mathrm{p} 50 \alpha$, $\mathrm{p} 85 \beta$, p $55 \gamma$ regulatory and $\mathrm{p} 110 \alpha, \mathrm{p} 110 \beta, \mathrm{p} 110 \delta$ catalytic) that are the products of distinct genes diversified by alternative splicing (Shepherd et al. 1998). Regulatory and catalytic subunits appear to associate in all possible combinations, subject to their relative expression. Regulatory subunits are normally in excess, competing with active heterodimers for binding to IRSs and antagonising function by other mechanisms (Taniguchi et al. 2006). Several studies have suggested that insulin signals primarily via $\mathrm{p} 110 \alpha$ although the mechanism for such selectivity is unclear (Foukas et al. 2006, Knight et al. 2006, Sopasakis et al. 2010). However, other studies indicate roles for both $\mathrm{p} 110 \alpha$ and $\mathrm{p} 110 \beta$ in insulin signalling, with evidence of functional redundancy or complementarity (Brachmann et al. 2005, Chaussade et al. 2007, Jia et al. 2008, Tups et al. 2010).

The lipid product of PI3Ks, PtdIns $(3,4,5) \mathrm{P} 3$, induces the activation of protein serine kinase cascades by co-recruitment to membranes of phosphoinositidedependent kinase-1 (PDK1) and its substrate kinases Akt/PKB and atypical protein kinase Cs (aPKCs), via their respective PH domains (Mora et al. 2004). PDK1 activates Akt/PKB and aPKC by phosphorylation of serine/threonine residues in their kinase regulatory loops (Pearce et al. 2010). Activation of Akt/PKB additionally requires phosphorylation of a C-terminal hydrophobic motif, catalysed by a distinct enzyme, most probably mTORC2 or DNA-PK (Bozulic \& Hemmings 2009). The duration and amplitude of Akt signalling are controlled by PHLPP, a phosphatase that acts specifically on the hydrophobic phosphorylation motif (Brognard \& Newton 2008).

Activated Akt/PKB phosphorylates multiple substrates and controls a variety of downstream responses depending on cell type (Manning \& Cantley 2007, Vasudevan \& Garraway 2010). In some cases, phosphorylation of targets itself regulates activity, while in others binding of 14-3-3 protein also plays a role (Johnson et al. 2010). There are three isoforms of Akt/PKB encoded by distinct genes, and functional specificity of isoforms has been demonstrated in signalling to metabolism and growth (Dummler \& Hemmings 2007, Gonzalez \& McGraw 2009, Schultze et al. 2011). Well-established Akt/PKB substrates include GSK-3, regulating glycogen synthesis; the Rab GTPase activating protein AS160/TBC1D4, regulating glucose transport; the Rheb GTPase activating complex TSC1/2, regulating mTOR and protein synthesis; FOXO transcription factors, regulating expression of gluconeogenic and other genes; and $\mathrm{BAD}$, regulating apoptosis (Manning \& Cantley 2007, Vasudevan \& Garraway 2010). Both Akt-dependent and -independent mechanisms have been implicated in regulation of adipose tissue lipolysis by insulin (Berggreen et al. 2009, Choi et al. 2010). The precise functions of aPKCs are less understood (Hirai \& Chida 2003, Rosse et al. 2010).

Enzymatic and proteomic techniques (Cohen \& Knebel 2006, Choudhary \& Mann 2010) and bioinformatic tools (Miller \& Blom 2009) have been developed for the discovery and prediction of cellular substrates of $\mathrm{Akt} / \mathrm{PKB}$ and other kinases. However, identification of potential Akt substrates has outstripped their validation as important physiological targets (Manning \& Cantley 2007). The problem is well illustrated by the finding that allosteric regulation of glycogen synthase by glucose 6-phosphate, rather than covalent regulation by the Akt/GSK-3 cascade, is the major mechanism by which insulin stimulates muscle glycogen synthesis in vivo (Bouskila et al. 2010).

Activation of Akt/PKB mediates insulin-stimulated translocation of GLUT4 glucose transporters in muscle and adipose tissue (Whiteman et al. 2002), although aPKC $\zeta / \lambda$ can apparently play a similar role (Farese \& Sajan 2010). Whether activation of either kinase is sufficient for a maximum response is less clear and additional mechanisms may also be required. These include actin remodelling mediated by activation of Rho family GTPases such as TC10 (Chang et al. 2004) and Rac1 (Ishikura et al. 2008). It is likely that regulation is exerted at multiple steps of GLUT4 traffic, including the release or budding of vesicles from their storage pool, movement to and docking with the plasma membrane and fusion with the plasma membrane (Watson \& Pessin 2007, Larance et al. 2008). The Akt/PKB substrate AS160/TBC1D4, whose Rab GAP activity is inhibited by insulin-induced phosphorylation, has emerged as a key component of regulation of GLUT4 traffic although its site of action is uncertain (Sakamoto \& Holman 2008, Chen et al. 2011). The Rabs and their effectors that are activated as a consequence of AS160 phosphorylation have yet to be conclusively identified (Sano et al. 2008). 


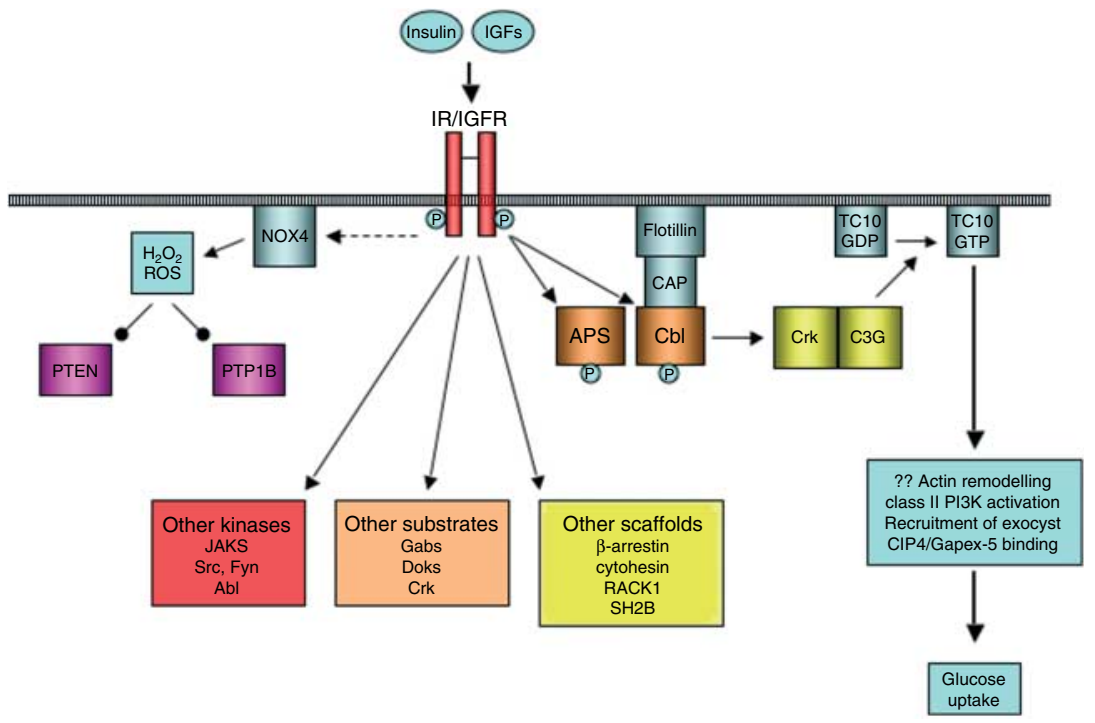

Figure 2 Additional pathways and components. Some accessory components of insulin/IGF signalling pathways are indicated: tyrosine kinases (in red), tyrosinephosphorylated substrates (in orange), adaptors and transducers (in yellow and grey) and negative regulators (in purple).

\section{Ras/MAP kinase pathway}

In common with many receptor tyrosine kinases, IR and IGFR regulate cell growth-related gene expression via the Ras/MAP kinase pathway (Avruch 2007). The pathway is initiated by recruitment of the adaptor/ guanine nucleotide exchange factor complex Grb2/Sos to phosphorylated Shc and/or IRSs. It is unclear whether Shc-bound and IRS-bound Grb2/Sos complexes are equally effective activators of Ras, given the differences in their abundance, subcellular localisation and potential co-recruitment of additional components. In some cells, Shc is the more important substrate for Ras/MAP kinase activation (Pruett et al. 1995), while in others, IRS-dependent pathways appear to predominate (Takahashi et al. 1997). Shc and IRSs may compete in binding to IR/IGFR and in recruiting a limited pool of Grb2, and this could influence signalling to 'metabolic' versus 'mitogenic' responses (Sasaoka et al. 2001).

Activation of Ras by Sos depends on mutual proximity and relief of Sos autoinhibition (Gureasko et al. 2008). Activated (GTP-bound) Ras in turn activates the kinase Raf, the dual specificity kinase MEK, MAP kinase/ERK and further downstream kinases (Ramos 2008). Scaffold proteins play a role in co-ordinating this cascade, and may influence cellular responses through effects on signal intensity and duration, localisation of complexes and recruitment of modulatory proteins such as phosphatases and ubiquitin ligases (Brown \& Sacks 2009). Functional differences between isoforms of MAP kinase (ERK1/2) and MAP kinase (MEK1/2) have been discussed in relation to cell cycle regulation (Sturgill 2008).

\section{Additional pathways}

Various accessory pathways, kinases, adaptor proteins and scaffolds have been implicated in modulating IR/IGFR signalling via PI3K/Akt and Ras/MAP kinase pathways (Fig. 2).

\section{Redox: PTPs and PTEN}

Evidence from cellular studies indicates that activation of IR/IGFR (and certain other RTKs) promotes generation of reactive oxygen and nitrogen species, which inhibit protein and lipid phosphatases including PTP1B and PTEN by reversible modification of activesite cysteine residues, and thereby potentiate the effects of tyrosine phosphorylation and PI3K activation (Goldstein et al. 2005, Vardatsikos et al. 2009, Hsu \& Meng 2010). The NAD(P)H oxidase homologue Nox4 has been identified as a likely source of insulin/IGFstimulated $\mathrm{H}_{2} \mathrm{O}_{2}$ generation (Goldstein et al. 2005, Meng et al. 2008) but the mechanisms coupling IR/IGFR signalling to Nox4 activation remain obscure. Evidence from mouse knockout models confirms that reactive oxygen species enhance insulin sensitivity in vivo (Loh et al. 2009), although chronic oxidative stress contributes to the development of insulin resistance and diabetic complications (Cheng et al. 2010, Giacco \& Brownlee 2010). 


\section{CAP/Cbl pathway: IR and glucose uptake}

It has been proposed that stimulation of glucose transport by insulin involves a second pathway in addition to PI3K/Akt. This Cbl-associated protein (CAP)/Cbl pathway is initiated by tyrosine phosphorylation of the adaptors APS and c-Cbl (Ahn et al. 2004, Hu \& Hubbard 2005), leading to assembly of a signalling complex that is localised to lipid rafts by CAP and resulting in activation of TC10, a member of the Rho family of small GTPases (Chang et al. 2004). Effector mechanisms that might link TC10 to glucose transport include actin remodelling, assembly of exocyst complexes and generation of PtdIns3P (Chang et al. 2004, Falasca et al. 2007). However, the physiological importance of the CAP/Cbl pathway in IR/IGFR function is uncertain. The pathway does not appear to operate in skeletal muscle (JeBailey et al. 2004), knockdown of key components does not disrupt insulin-stimulated glucose transport in adipocytes (Mitra et al. 2004) and knockout of APS or c-Cbl in mice actually improves peripheral insulin sensitivity (Minami et al. 2003, Molero et al. 2004, Li et al. 2006).

\section{Other phosphoinositides: class II and III PI3Ks, PIKfyve}

In addition to the well-established roles of class Ia PI3Ks, class II and class III PI3Ks and PIKfyve may play roles in signalling (Shisheva 2008a, Falasca \& Maffucci 2009). Class II PI3Ks, whose in vivo product is PtdIns3P, have been implicated in regulation of glucose transport in muscle (Falasca et al. 2007) and gene expression in pancreatic $\beta$-cells (Leibiger et al. 2010b). PIKfyve, which synthesises PtdIns5P and PtdIns(3,5)P2 and binds to PtdIns3P via its fyve domain, is phosphorylated by Akt and may be involved in GLUT4 translocation (Berwick et al. 2004). Dysfunction of PIKfyve produces endosome enlargement and cytoplasmic vacuolation (Shisheva $2008 b$ ), suggesting a general role in maintaining subcellular membrane compartments rather than a specific role in insulin signalling.

\section{Other potential signalling components}

It is outside the scope of this brief review to consider in detail other proteins that may play roles in insulin/IGF action, many of them more closely associated with other signalling pathways. However, in addition to IRSs, Shc, APS and c-Cbl discussed above, Gabs (Nishida \& Hirano 2003) and DOKs (Mashima et al. 2009) are substrates for IR and IGFR tyrosine kinases. Insulin and IGFs have been reported to activate nonreceptor TKs, including JAKs (Himpe \& Kooijman 2009), Src family kinases (Bromann et al. 2004) and
c-Abl (Sirvent et al. 2008). Other proteins implicated in actions of insulin or IGFs include SH2-B (an adaptor protein related to APS) (Duan et al. 2004, Li et al. 2006, Morris et al. 2009), cytohesins (guanine nucleotide exchange factors for ARF family GTPases; Fuss et al. 2006, Hafner et al. 2006), the scaffold CNK1 (Lim et al. 2010), the WD repeat protein RACK1 (Kiely et al. 2008, 2009) and $\beta$-arrestins (Luan et al. 2009). The mechanisms of involvement of these proteins in insulin/IGF signalling pathways are largely speculative and require further study.

\section{Conclusion}

Many details of insulin/IGF signalling remain to be clarified, including the specific roles of receptor isoforms and hybrid receptors; the role of accessory pathways, kinases and scaffolds in modulating or supplementing canonical PI3K/Akt and Ras/MAP kinase pathways; the precise mechanisms underlying the regulated trafficking of GLUT4 glucose transporters; and the feedback and crosstalk mechanisms that modulate signalling under different physiological and pathological conditions. In relation to the longstanding issue of insulin/IGF signalling specificity, recent studies suggest that 'IR and IGFR act as identical portals for the regulation of gene expression, with differences between insulin and IGF1 effects due to a modulation of the amplitude of the signal created by the specific ligand-receptor interaction' (Boucher et al. 2010). However, mechanisms that might impart a degree of specificity to insulin and IGF responses are still being actively considered, focused largely on the influence of ligand-binding mechanism and kinetics (Jensen \& De Meyts 2009). In spite of the wealth of information that has accumulated concerning IR and IGFR signalling pathways in the 25 years since the receptors were cloned, the precise nature and even the very existence of receptor-specific signalling mechanisms remain enigmatic.

\section{Declaration of interest}

The author declares that there is no conflict of interest that could be perceived as prejudicing the impartiality of the research reported.

\section{Funding}

K S is a member of the Medical Research Council Centre for Obesity and Related Metabolic Diseases (MRC CORD) and of European Union COST Action BM0602. Work in the K S laboratory is currently supported by Diabetes UK (Project Grant RD07/0003531) and BBSRC (Project Grant BB/F-15364/1). 


\section{References}

Adams TE, McKern NM \& Ward CW 2004 Signalling by the type 1 insulin-like growth factor receptor: interplay with the epidermal growth factor receptor. Growth Factors 22 89-95. (doi:10.1080/ 08977190410001700998)

Ahn MY, Katsanakis KD, Bheda F \& Pillay TS 2004 Primary and essential role of the adaptor protein APS for recruitment of both c-Cbl and its associated protein CAP in insulin signaling. Journal of Biological Chemistry 279 21526-21532. (doi:10.1074/jbc. M307740200)

Aleksic T, Chitnis MM, Perestenko OV, Gao S, Thomas PH, Turner GD, Protheroe AS, Howarth M \& Macaulay VM 2010 Type 1 insulin-like growth factor receptor translocates to the nucleus of human tumor cells. Cancer Research 70 6412-6419. (doi:10.1158/0008-5472.CAN10-0052)

Avruch J 2007 MAP kinase pathways: the first twenty years. Biochimica et Biophysica Acta 1773 1150-1160. (doi:10.1016/j.bbamcr.2006.11. 006)

Belfiore A, Frasca F, Pandini G, Sciacca L \& Vigneri R 2009 Insulin receptor isoforms and insulin receptor/insulin-like growth factor receptor hybrids in physiology and disease. Endocrine Reviews 30 586-623. (doi:10.1210/er.2008-0047)

Berggreen C, Gormand A, Omar B, Degerman E \& Goransson O 2009 Protein kinase $\mathrm{B}$ activity is required for the effects of insulin on lipid metabolism in adipocytes. American Journal of Physiology. Endocrinology and Metabolism 296 E635-E646. (doi:10.1152/ajpendo. 90596.2008)

Berwick DC, Dell GC, Welsh GI, Heesom KJ, Hers I, Fletcher LM, Cooke FT \& Tavare JM 2004 Protein kinase B phosphorylation of PIKfyve regulates the trafficking of GLUT4 vesicles. Journal of Cell Science 117 5985-5993. (doi:10.1242/jcs.01517)

Boucher J, Tseng YH \& Kahn CR 2010 Insulin and insulin-like growth factor-1 receptors act as ligand-specific amplitude modulators of a common pathway regulating gene transcription. Journal of Biological Chemistry 285 17235-17245. (doi:10.1074/jbc.M110.118620)

Boura-Halfon S \& Zick Y 2009 Phosphorylation of IRS proteins, insulin action, and insulin resistance. American Journal of Physiology. Endocrinology and Metabolism 296 E581-E591. (doi:10.1152/ajpendo. 90437.2008)

Bouskila M, Hunter RW, Ibrahim AF, Delattre L, Peggie M, van Diepen JA, Voshol PJ, Jensen J \& Sakamoto K 2010 Allosteric regulation of glycogen synthase controls glycogen synthesis in muscle. Cell Metabolism 12 456-466. (doi:10.1016/j.cmet.2010.10.006)

Bouzakri K, Zachrisson A, Al-Khalili L, Zhang BB, Koistinen HA, Krook A \& Zierath JR 2006 siRNA-based gene silencing reveals specialized roles of IRS-1/Akt2 and IRS-2/Akt1 in glucose and lipid metabolism in human skeletal muscle. Cell Metabolism 4 89-96. (doi:10.1016/j.cmet. 2006.04.008)

Bozulic L \& Hemmings BA 2009 PIKKing on PKB: regulation of PKB activity by phosphorylation. Current Opinion in Cell Biology 21 256-261. (doi:10.1016/j.ceb.2009.02.002)

Brachmann SM, Ueki K, Engelman JA, Kahn RC \& Cantley LC 2005 Phosphoinositide 3-kinase catalytic subunit deletion and regulatory subunit deletion have opposite effects on insulin sensitivity in mice. Molecular and Cellular Biology 25 1596-1607. (doi:10.1128/MCB.25. 5.1596-1607.2005)

Brognard J \& Newton AC 2008 PHLiPPing the switch on Akt and protein kinase C signaling. Trends in Endocrinology and Metabolism 19 223-230. (doi:10.1016/j.tem.2008.04.001)

Bromann PA, Korkaya H \& Courtneidge SA 2004 The interplay between Src family kinases and receptor tyrosine kinases. Oncogene 23 7957-7968. (doi:10.1038/sj.onc.1208079)

Brown MD \& Sacks DB 2009 Protein scaffolds in MAP kinase signalling. Cellular Signalling 21 462-469. (doi:10.1016/j.cellsig.2008.11.013)

Chang L, Chiang SH \& Saltiel AR 2004 Insulin signaling and the regulation of glucose transport. Molecular Medicine 10 65-71. (doi:10.2119/2005-00029.Saltiel)
Chaussade C, Rewcastle GW, Kendall JD, Denny WA, Cho K, Gronning LM, Chong ML, Anagnostou SH, Jackson SP, Daniele N et al. 2007 Evidence for functional redundancy of class IA PI3K isoforms in insulin signalling. Biochemical Journal 404 449-458. (doi:10.1042/ BJ20070003)

Chen S, Wasserman DH, MacKintosh C \& Sakamoto K 2011 Mice with AS160/TBC1D4-Thr649Ala knockin mutation are glucose intolerant with reduced insulin sensitivity and altered GLUT4 trafficking. Cell Metabolism 13 68-79. (doi:10.1016/j.cmet.2010.12.005)

Cheng Z, Tseng Y \& White MF 2010 Insulin signaling meets mitochondria in metabolism. Trends in Endocrinology and Metabolism 21 589-598. (doi:10.1016/j.tem.2010.06.005)

Choi SM, Tucker DF, Gross DN, Easton RM, DiPilato LM, Dean AS, Monks BR \& Birnbaum MJ 2010 Insulin regulates adipocyte lipolysis via an Akt-independent signaling pathway. Molecular and Cellular Biology 30 5009-5020. (doi:10.1128/MCB.00797-10)

Choudhary C \& Mann M 2010 Decoding signalling networks by mass spectrometry-based proteomics. Nature Reviews. Molecular Cell Biology 11 427-439. (doi:10.1038/nrm2900)

Cohen P 2006 The twentieth century struggle to decipher insulin signalling. Nature Reviews. Molecular Cell Biology 7 867-873. (doi:10. $1038 /$ nrm2043)

Cohen P \& Knebel A 2006 KESTREL: a powerful method for identifying the physiological substrates of protein kinases. Biochemical Journal 393 1-6. (doi:10.1042/BJ20051545)

De Meyts P 2008 The insulin receptor: a prototype for dimeric, allosteric membrane receptors? Trends in Biochemical Sciences 33 376-384. (doi:10.1016/j.tibs.2008.06.003)

Duan C, Yang H, White MF \& Rui L 2004 Disruption of the SH2-B gene causes age-dependent insulin resistance and glucose intolerance. Molecular and Cellular Biology 24 7435-7443. (doi:10.1128/MCB.24. 17.7435-7443.2004)

Dube N \& Tremblay ML 2005 Involvement of the small protein tyrosine phosphatases TC-PTP and PTP1B in signal transduction and diseases: from diabetes, obesity to cell cycle, and cancer. Biochimica et Biophysica Acta 1754 108-117. (doi:10.1016/j.bbapap. 2005.07.030)

Dummler B \& Hemmings BA 2007 Physiological roles of PKB/Akt isoforms in development and disease. Biochemical Society Transactions 35 231-235. (doi:10.1042/BST0350231)

Dumont JE, Dremier S, Pirson I \& Maenhaut C 2002 Cross signaling, cell specificity, and physiology. American Journal of Physiology. Cell Physiology 283 C2-C28. (doi:10.1152/ajpcell.00581.2001)

Falasca M \& Maffucci T 2009 Rethinking phosphatidylinositol 3-monophosphate. Biochimica et Biophysica Acta 1793 1795-1803. (doi:10.1016/j.bbamcr.2009.10.003)

Falasca M, Hughes WE, Dominguez V, Sala G, Fostira F, Fang MQ, Cazzolli R, Shepherd PR, James DE \& Maffucci T 2007 The role of phosphoinositide 3-kinase C2alpha in insulin signaling. Journal of Biological Chemistry 282 28226-28236. (doi:10.1074/jbc. M704357200)

Farese RV \& Sajan MP 2010 Metabolic functions of atypical protein kinase C: "good" and "bad" as defined by nutritional status. American Journal of Physiology. Endocrinology and Metabolism 298 E385-E394. (doi:10.1152/ajpendo.00608.2009)

Foti M, Moukil MA, Dudognon P \& Carpentier JL 2004 Insulin and IGF-1 receptor trafficking and signalling. Novartis Foundation Symposium 262 125-141.

Foukas LC, Claret M, Pearce W, Okkenhaug K, Meek S, Peskett E, Sancho S, Smith AJ, Withers DJ \& Vanhaesebroeck B 2006 Critical role for the p110alpha phosphoinositide-3-OH kinase in growth and metabolic regulation. Nature 441 366-370. (doi:10.1038/nature04694)

Fritsche L, Neukamm SS, Lehmann R, Kremmer E, Hennige AM, Hunder-Gugel A, Schenk M, Haring HU, Schleicher ED \& Weigert C 2011 Insulin-induced serine phosphorylation of IRS-2 via Erk1/2 and mTOR: studies on the function of Ser 675 and Ser 907. American Journal of Physiology. Endocrinology and Metabolism 300 E824-E836. (doi:10.1152/ajpendo.00409.2010) 
Fuss B, Becker T, Zinke I \& Hoch M 2006 The cytohesin Steppke is essential for insulin signalling in Drosophila. Nature 444 945-948. (doi:10.1038/nature05412)

Garfield AS, Cowley M, Smith FM, Moorwood K, Stewart-Cox JE, Gilroy K, Baker S, Xia J, Dalley JW, Hurst LD et al. 2011 Distinct physiological and behavioural functions for parental alleles of imprinted Grb10. Nature 469 534-538. (doi:10.1038/nature 09651)

Giacco F \& Brownlee M 2010 Oxidative stress and diabetic complications. Circulation Research 107 1058-1070. (doi:10.1161/ CIRCRESAHA.110.223545)

Goldfine ID, Maddux BA, Youngren JF, Reaven G, Accili D, Trischitta V, Vigneri R \& Frittitta L 2008 The role of membrane glycoprotein plasma cell antigen 1/ectonucleotide pyrophosphatase phosphodiesterase 1 in the pathogenesis of insulin resistance and related abnormalities. Endocrine Reviews 29 62-75. (doi:10.1210/er.20070004)

Goldstein BJ, Mahadev K, Wu X, Zhu L \& Motoshima H 2005 Role of insulin-induced reactive oxygen species in the insulin signaling pathway. Antioxidants E Redox Signaling 7 1021-1031. (doi:10.1089/ ars.2005.7.1021)

Gonzalez E \& McGraw TE 2009 The Akt kinases: isoform specificity in metabolism and cancer. Cell Cycle 8 2502-2508. (doi:10.4161/cc.8. 16.9335)

Gureasko J, Galush WJ, Boykevisch S, Sondermann H, Bar-Sagi D, Groves JT \& Kuriyan J 2008 Membrane-dependent signal integration by the Ras activator Son of sevenless. Nature Structural and Molecular Biology 15 452-461. (doi:10.1038/nsmb.1418)

Hafner M, Schmitz A, Grune I, Srivatsan SG, Paul B, Kolanus W, Quast T, Kremmer E, Bauer I \& Famulok M 2006 Inhibition of cytohesins by SecinH3 leads to hepatic insulin resistance. Nature 444 941-944. (doi:10.1038/nature05415)

Hanke S \& Mann M 2009 The phosphotyrosine interactome of the insulin receptor family and its substrates IRS-1 and IRS-2. Molecular and Cellular Proteomics 8 519-534. (doi:10.1074/mcp.M800407MCP200)

Himpe E \& Kooijman R 2009 Insulin-like growth factor-I receptor signal transduction and the Janus kinase/signal transducer and activator of transcription (JAK-STAT) pathway. Biofactors 35 76-81. (doi:10.1002/biof.20)

Hirai T \& Chida K 2003 Protein kinase Czeta (PKCzeta): activation mechanisms and cellular functions. Journal of Biochemistry 133 1-7. (doi:10.1093/jb/mvg017)

Hoehn KL, Hohnen-Behrens C, Cederberg A, Wu LE, Turner N, Yuasa T, Ebina Y \& James DE 2008 IRS1-independent defects define major nodes of insulin resistance. Cell Metabolism 7 421-433. (doi:10.1016/ j.cmet.2008.04.005)

Holt LJ \& Siddle K 2005 Grb10 and Grb14: enigmatic regulators of insulin action - and more? Biochemical Journal 388 393-406. (doi:10. 1042/BJ20050216)

Holt LJ, Lyons RJ, Ryan AS, Beale SM, Ward A, Cooney GJ \& Daly RJ 2009 Dual ablation of Grb10 and Grb14 in mice reveals their combined role in regulation of insulin signaling and glucose homeostasis. Molecular Endocrinology 23 1406-1414. (doi:10.1210/ me.2008-0386)

Hsu MF \& Meng TC 2010 Enhancement of insulin responsiveness by nitric oxide-mediated inactivation of protein-tyrosine phosphatases. Journal of Biological Chemistry 285 7919-7928. (doi:10.1074/jbc. M109.057513)

Hu J \& Hubbard SR 2005 Structural characterization of a novel Cbl phosphotyrosine recognition motif in the APS family of adapter proteins. Journal of Biological Chemistry 280 18943-18949. (doi:10. 1074/jbc.M414157200)

Huang SM, Hancock MK, Pitman JL, Orth AP \& Gekakis N 2009 Negative regulators of insulin signaling revealed in a genome-wide functional screen. PLoS ONE 4 e6871. (doi:10.1371/journal.pone. 0006871)
Ishikura S, Koshkina A \& Klip A 2008 Small G proteins in insulin action: Rab and Rho families at the crossroads of signal transduction and GLUT4 vesicle traffic. Acta Physiologica 192 61-74. (doi:10.1111/j.1748-1716.2007.01778.x)

JeBailey L, Rudich A, Huang X, Di Ciano-Oliveira C, Kapus A \& Klip A 2004 Skeletal muscle cells and adipocytes differ in their reliance on TC10 and Rac for insulin-induced actin remodeling. Molecular Endocrinology 18 359-372. (doi:10.1210/me.2003-0294)

Jensen M \& De Meyts P 2009 Molecular mechanisms of differential intracellular signaling from the insulin receptor. Vitamins and Hormones 80 51-75. (doi:10.1016/S0083-6729(08)00603-1)

Jia S, Liu Z, Zhang S, Liu P, Zhang L, Lee SH, Zhang J, Signoretti S, Loda M, Roberts TM et al. 2008 Essential roles of PI(3) K-p110beta in cell growth, metabolism and tumorigenesis. Nature $\mathbf{4 5 4} 776-779$. (doi:10.1038/nature07091)

Johnson C, Crowther S, Stafford MJ, Campbell DG, Toth R \& MacKintosh C 2010 Bioinformatic and experimental survey of 14-3-3-binding sites. Biochemical Journal 427 69-78. (doi:10.1042/ BJ20091834)

Kiely PA, Baillie GS, Lynch MJ, Houslay MD \& O'Connor R 2008 Tyrosine 302 in RACK1 is essential for insulin-like growth factor-I-mediated competitive binding of PP2A and betal integrin and for tumor cell proliferation and migration. Journal of Biological Chemistry 283 22952-22961. (doi:10.1074/jbc. M800802200)

Kiely PA, Baillie GS, Barrett R, Buckley DA, Adams DR, Houslay MD \& O'Connor R 2009 Phosphorylation of RACK1 on tyrosine 52 by $\mathrm{c}-\mathrm{Abl}$ is required for insulin-like growth factor I-mediated regulation of focal adhesion kinase. Journal of Biological Chemistry 284 20263-20274. (doi:10.1074/jbc.M109.017640)

Kiselyov VV, Versteyhe S, Gauguin L \& De Meyts P 2009 Harmonic oscillator model of the insulin and IGF1 receptors' allosteric binding and activation. Molecular Systems Biology 5243. (doi:10.1038/msb.2008.78)

Klein AL, Berkaw MN, Buse MG \& Ball LE 2009 O-linked $\mathrm{N}$-acetylglucosamine modification of insulin receptor substrate-1 occurs in close proximity to multiple SH2 domain binding motifs. Molecular and Cellular Proteomics 8 2733-2745. (doi:10.1074/mcp. M900207-MCP200)

Knight ZA, Gonzalez B, Feldman ME, Zunder ER, Goldenberg DD, Williams O, Loewith R, Stokoe D, Balla A, Toth B et al. 2006 A pharmacological map of the PI3-K family defines a role for p110alpha in insulin signaling. Cell 125 733-747. (doi:10.1016/ j.cell.2006.03.035)

Larance M, Ramm G \& James DE 2008 The GLUT4 code. Molecular Endocrinology 22 226-233. (doi:10.1210/me.2007-0282)

Laviola L, Natalicchio A \& Giorgino F 2007 The IGF-I signaling pathway. Current Pharmaceutical Design 13 663-669. (doi:10.2174/ 138161207780249146)

Lawrence MC, McKern NM \& Ward CW 2007 Insulin receptor structure and its implications for the IGF-1 receptor. Current Opinion in Structural Biology 17 699-705. (doi:10.1016/j.sbi.2007. 07.007)

Lebrun P \& Van Obberghen E 2008 SOCS proteins causing trouble in insulin action. Acta Physiologica 192 29-36. (doi:10.1111/j.17481716.2007.01782.x)

Leibiger IB, Brismar K \& Berggren PO $2010 a$ Novel aspects on pancreatic beta-cell signal-transduction. Biochemical and Biophysical Research Communications 396 111-115. (doi:10.1016/j.bbrc.2010.02. 174)

Leibiger B, Moede T, Uhles S, Barker CJ, Creveaux M, Domin J, Berggren PO \& Leibiger IB $2010 b$ Insulin-feedback via PI3KC2alpha activated PKBalpha/Akt1 is required for glucose-stimulated insulin secretion. FASEB Journal 24 1824-1837. (doi:10.1096/ fj.09-148072)

Li M, Ren D, Iseki M, Takaki S \& Rui L 2006 Differential role of SH2-B and APS in regulating energy and glucose homeostasis. Endocrinology 147 2163-2170. (doi:10.1210/en.2005-1313) 
Li S, Brown MS \& Goldstein JL 2010 Bifurcation of insulin signaling pathway in rat liver: mTORC1 required for stimulation of lipogenesis, but not inhibition of gluconeogenesis. PNAS 107 3441-3446. (doi:10.1073/pnas.0914798107)

Lim J, Zhou M, Veenstra TD \& Morrison DK 2010 The CNK1 scaffold binds cytohesins and promotes insulin pathway signaling. Genes and Development 24 1496-1506. (doi:10.1101/gad.1904610)

Liu BA, Jablonowski K, Shah EE, Engelmann BW, Jones RB \& Nash PD 2010 SH2 domains recognize contextual peptide sequence information to determine selectivity. Molecular and Cellular Proteomics 9 2391-2404. (doi:10.1074/mcp.M110.001586)

Loh K, Deng H, Fukushima A, Cai X, Boivin B, Galic S, Bruce C, Shields BJ, Skiba B, Ooms LM et al. 2009 Reactive oxygen species enhance insulin sensitivity. Cell Metabolism 10 260-272. (doi:10. 1016/j.cmet.2009.08.009)

Luan B, Zhao J, Wu H, Duan B, Shu G, Wang X, Li D, Jia W, Kang J \& Pei G 2009 Deficiency of a beta-arrestin-2 signal complex contributes to insulin resistance. Nature 457 1146-1149. (doi:10. 1038/nature07617)

Manning BD \& Cantley LC 2007 AKT/PKB, signaling: navigating downstream. Cell 129 1261-1274. (doi:10.1016/j.cell.2007.06.009)

Mashima R, Hishida Y, Tezuka T \& Yamanashi Y 2009 The roles of Dok family adapters in immunoreceptor signaling. Immunological Reviews 232 273-285. (doi:10.1111/j.1600-065X.2009.00844.x)

Meng D, Lv DD \& Fang J 2008 Insulin-like growth factor-I induces reactive oxygen species production and cell migration through Nox4 and Rac1 in vascular smooth muscle cells. Cardiovascular Research 80 299-308. (doi:10.1093/cvr/cvn173)

Miller ML \& Blom N 2009 Kinase-specific prediction of protein phosphorylation sites. Methods in Molecular Biology 527 299-310. (doi:10.1007/978-1-60327-834-8_22)

Minami A, Iseki M, Kishi K, Wang M, Ogura M, Furukawa N, Hayashi S, Yamada M, Obata T, Takeshita Y et al. 2003 Increased insulin sensitivity and hypoinsulinemia in APS knockout mice. Diabetes 52 2657-2665. (doi:10.2337/diabetes.52.11.2657)

Mitra P, Zheng X \& Czech MP 2004 RNAi-based analysis of CAP, Cbl, and CrkII function in the regulation of GLUT4 by insulin. Journal of Biological Chemistry 279 37431-37435. (doi:10.1074/jbc.C400180200)

Molero JC, Jensen TE, Withers PC, Couzens M, Herzog H, Thien CB, Langdon WY, Walder K, Murphy MA, Bowtell DD et al. 2004 c-Cbldeficient mice have reduced adiposity, higher energy expenditure, and improved peripheral insulin action. Journal of Clinical Investigation 114 1326-1333. (doi:10.1172/JCI21480)

Mora A, Komander D, van Aalten DM \& Alessi DR 2004 PDK1, the master regulator of AGC kinase signal transduction. Seminars in Cell and Developmental Biology 15 161-170. (doi:10.1016/j.semcdb.2003. 12.022)

Morris DL, Cho KW, Zhou Y \& Rui L 2009 SH2B1 enhances insulin sensitivity by both stimulating the insulin receptor and inhibiting tyrosine dephosphorylation of insulin receptor substrate proteins. Diabetes 58 2039-2047. (doi:10.2337/db08-1388)

Nakae J, Kido Y \& Accili D 2001 Distinct and overlapping functions of insulin and IGF-I receptors. Endocrine Reviews 22 818-835. (doi:10. $1210 /$ er.22.6.818)

Narasimhan SD, Yen K \& Tissenbaum HA 2009 Converging pathways in lifespan regulation. Current Biology 19 R657-R666. (doi:10.1016/ j.cub.2009.06.013)

Nelson JD, LeBoeuf RC \& Bomsztyk K 2011 Direct recruitment of insulin receptor and ERK signaling cascade to insulin-inducible gene loci. Diabetes 60 127-137. (doi:10.2337/db09-1806)

Nishida K \& Hirano T 2003 The role of Gab family scaffolding adapter proteins in the signal transduction of cytokine and growth factor receptors. Cancer Science 94 1029-1033. (doi:10.1111/j.1349-7006. 2003.tb01396.x)

Nouaille S, Blanquart C, Zilberfarb V, Boute N, Perdereau D, Roix J, Burnol AF \& Issad T 2006 Interaction with Grb14 results in sitespecific regulation of tyrosine phosphorylation of the insulin receptor. EMBO Reports 7 512-518. (doi:10.1038/sj.embor.7400668)
Pearce LR, Komander D \& Alessi DR 2010 The nuts and bolts of AGC protein kinases. Nature Reviews. Molecular Cell Biology 11 9-22. (doi:10.1038/nrm2822)

Pollak M 2008 Insulin and insulin-like growth factor signalling in neoplasia. Nature Reviews. Cancer 8 915-928. (doi:10.1038/nrc2536)

Pruett W, Yuan Y, Rose E, Batzer AG, Harada N \& Skolnik EY 1995 Association between GRB2/Sos and insulin receptor substrate 1 is not sufficient for activation of extracellular signal-regulated kinases by interleukin-4: implications for Ras activation by insulin. Molecular and Cellular Biology 15 1778-1785.

Ramos JW 2008 The regulation of extracellular signal-regulated kinase (ERK) in mammalian cells. International Journal of Biochemistry and Cell Biology 40 2707-2719. (doi:10.1016/j.biocel.2008.04.009)

Ramos FJ, Langlais PR, Hu D, Dong LQ \& Liu F 2006 Grb10 mediates insulin-stimulated degradation of the insulin receptor: a mechanism of negative regulation. American Journal of Physiology. Endocrinology and Metabolism 290 E1262-E1266. (doi:10.1152/ ajpendo.00609.2005)

Romanelli RJ, LeBeau AP, Fulmer CG, Lazzarino DA, Hochberg A \& Wood TL 2007 Insulin-like growth factor type-I receptor internalization and recycling mediate the sustained phosphorylation of Akt. Journal of Biological Chemistry 282 22513-22524. (doi:10.1074/jbc. M704309200)

Rosse C, Linch M, Kermorgant S, Cameron AJ, Boeckeler K \& Parker PJ 2010 PKC and the control of localized signal dynamics. Nature Reviews. Molecular Cell Biology 11 103-112. (doi:10.1038/nrm2847)

Sakamoto K \& Holman GD 2008 Emerging role for AS160/TBC1D4 and TBC1D1 in the regulation of GLUT4 traffic. American Journal of Physiology. Endocrinology and Metabolism 295 E29-E37. (doi:10.1152/ ajpendo.90331.2008)

Sano H, Roach WG, Peck GR, Fukuda M \& Lienhard GE 2008 Rab10 in insulin-stimulated GLUT4 translocation. Biochemical Journal 411 89-95. (doi:10.1042/BJ20071318)

Sasaoka T, Ishiki M, Wada T, Hori H, Hirai H, Haruta T, Ishihara H \& Kobayashi M 2001 Tyrosine phosphorylation-dependent and -independent role of Shc in the regulation of IGF-1-induced mitogenesis and glycogen synthesis. Endocrinology 142 5226-5235. (doi:10.1210/en.142.12.5226)

Schultze SM, Jensen J, Hemmings BA, Tschopp O \& Niessen M 2011 Promiscuous affairs of PKB/AKT isoforms in metabolism. Archives of Physiology and Biochemistry 117 70-77. (doi:10.3109/13813455.2010. 539236)

Sehat B, Tofigh A, Lin Y, Trocme E, Liljedahl U, Lagergren J \& Larsson O 2010 SUMOylation mediates the nuclear translocation and signaling of the IGF-1 receptor. Science Signaling 3 ra10. (doi:10.1126/scisignal. 2000628)

Shepherd PR, Withers DJ \& Siddle K 1998 Phosphoinositide 3-kinase: the key switch mechanism in insulin signalling. Biochemical Journal 333 471-490.

Shisheva A $2008 a$ Phosphoinositides in insulin action on GLUT4 dynamics: not just PtdIns(3,4,5)P3. American Journal of Physiology. Endocrinology and Metabolism 295 E536-E544. (doi:10.1152/ajpendo. 90353.2008)

Shisheva A 2008 $b$ PIKfyve: partners, significance, debates and paradoxes. Cell Biology International 32 591-604. (doi:10.1016/ j.cellbi.2008.01.006)

Sirvent A, Benistant C \& Roche S 2008 Cytoplasmic signalling by the c-Abl tyrosine kinase in normal and cancer cells. Biology of the Cell 100 617-631. (doi:10.1042/BC20080020)

Slawson C, Copeland RJ \& Hart GW 2010 O-GlcNAc signaling: a metabolic link between diabetes and cancer? Trends in Biochemical Sciences 35 547-555. (doi:10.1016/j.tibs.2010.04.005)

Smith FM, Holt LJ, Garfield AS, Charalambous M, Koumanov F, Perry M, Bazzani R, Sheardown SA, Hegarty BD, Lyons RJ et al. 2007 Mice with a disruption of the imprinted Grb10 gene exhibit altered body composition, glucose homeostasis, and insulin signaling during postnatal life. Molecular and Cellular Biology 27 5871-5886. (doi:10. 1128/MCB.02087-06) 
Sopasakis VR, Liu P, Suzuki R, Kondo T, Winnay J, Tran TT, Asano T, Smyth G, Sajan MP, Farese RV et al. 2010 Specific roles of the p110alpha isoform of phosphatidylinsositol 3-kinase in hepatic insulin signaling and metabolic regulation. Cell Metabolism 11 220-230. (doi:10.1016/j.cmet.2010.02.002)

Sturgill TW 2008 MAP kinase: it's been longer than fifteen minutes. Biochemical and Biophysical Research Communications 371 1-4. (doi:10. 1016/j.bbrc.2008.04.002)

Sun XJ \& Liu F 2009 Phosphorylation of IRS proteins Yin-Yang regulation of insulin signaling. Vitamins and Hormones 80 351-387. (doi:10.1016/S0083-6729(08)00613-4)

Takahashi Y, Tobe K, Kadowaki H, Katsumata D, Fukushima Y, Yazaki Y, Akanuma Y \& Kadowaki T 1997 Roles of insulin receptor substrate-1 and Shc on insulin-like growth factor I receptor signaling in early passages of cultured human fibroblasts. Endocrinology 138 741-750. (doi:10.1210/en.138.2.741)

Taniguchi CM, Ueki K \& Kahn R 2005 Complementary roles of IRS-1 and IRS-2 in the hepatic regulation of metabolism. Journal of Clinical Investigation 115 718-727. (doi:10.1172/JCI200523187)

Taniguchi CM, Emanuelli B \& Kahn CR 2006 Critical nodes in signalling pathways: insights into insulin action. Nature Reviews. Molecular Cell Biology 7 85-96. (doi:10.1038/nrm1837)

Thirone AC, Huang C \& Klip A 2006 Tissue-specific roles of IRS proteins in insulin signaling and glucose transport. Trends in Endocrinology and Metabolism 17 72-78. (doi:10.1016/j.tem.2006.01. 005)

Tups A, Anderson GM, Rizwan M, Augustine RA, Chaussade C, Shepherd PR \& Grattan DR 2010 Both p110alpha and p110beta isoforms of phosphatidylinositol 3-OH-kinase are required for insulin signalling in the hypothalamus. Journal of Neuroendocrinology 22 534-542. (doi:10.1111/j.1365-2826.2010.01975.x)

Vardatsikos G, Sahu A \& Srivastava AK 2009 The insulin-like growth factor family: molecular mechanisms, redox regulation, and clinical implications. Antioxidants Eै Redox Signaling 11 1165-1190. (doi:10. 1089/ars.2008.2161)

Vasudevan KM \& Garraway LA 2010 AKT signaling in physiology and disease. Current Topics in Microbiology and Immunology 347 105-133. (doi:10.1007/82_2010_66)
Vecchione A, Marchese A, Henry P, Rotin D \& Morrione A 2003 The Grb10/Nedd4 complex regulates ligand-induced ubiquitination and stability of the insulin-like growth factor I receptor. Molecular and Cellular Biology 23 3363-3372. (doi:10.1128/MCB.23.9.33633372.2003)

Watson RT \& Pessin JE 2007 GLUT4 translocation: the last 200 nanometers. Cellular Signalling 19 2209-2217. (doi:10.1016/j. cellsig.2007.06.003)

Whelan SA, Dias WB, Thiruneelakantapillai L, Lane MD \& Hart GW 2010 Regulation of insulin receptor substrate 1 (IRS-1)/AKT kinase-mediated insulin signaling by $O$-linked beta- $N$-acetylglucosamine in 3T3-L1 adipocytes. Journal of Biological Chemistry 285 5204-5211. (doi:10.1074/jbc.M109.077818)

White MF 2002 IRS proteins and the common path to diabetes. American Journal of Physiology. Endocrinology and Metabolism 283 E413-E422. (doi:10.1152/ajpendo.00514.2001)

Whiteman EL, Cho H \& Birnbaum MJ 2002 Role of Akt/protein kinase $\mathrm{B}$ in metabolism. Trends in Endocrinology and Metabolism 13 444-451. (doi:10.1016/S1043-2760 (02)00662-8)

Wu J, Tseng YD, Xu CF, Neubert TA, White MF \& Hubbard SR 2008 Structural and biochemical characterization of the KRLB region in insulin receptor substrate-2. Nature Structural and Molecular Biology 15 251-258. (doi:10.1038/nsmb.1388)

Yang X, Ongusaha PP, Miles PD, Havstad JC, Zhang F, So WV, Kudlow JE, Michell RH, Olefsky JM, Field SJ et al. 2008 Phosphoinositide signalling links $O$-GlcNAc transferase to insulin resistance. Nature 451 964-969. (doi:10.1038/nature06668)

Youngren JF 2007 Regulation of insulin receptor function. Cellular and Molecular Life Sciences 64 873-891. (doi:10.1007/s00018-007-6359-9)

Zeidan Q \& Hart GW 2010 The intersections between $O$-GlcNAcylation and phosphorylation: implications for multiple signaling pathways. Journal of Cell Science 123 13-22. (doi:10.1242/jcs.053678)

Received in final form 17 March 2011

Accepted 15 April 2011

Made available online as an Accepted Preprint 15 April 2011 